\title{
Association of Acid Fast Bacilli Positive Cases with ABO Blood Groups and Frequency of Distribution of ABO Blood Groups among North Bengalis In India
}

\author{
Dilip Kumar Mishra \\ Sonoscan Diagnostic Centre, Dakshin Dinajpur, West Bengal
}

\section{ABSTRACT}

Blood group in 44 cases of A.F.B positive patients and 3476 non-tubercular normal persons were determined. A relatively increased incidence of A.F.B positive cases were observed in persons with $\mathrm{O}$ blood group and blood group B was observed as commonest group among north Bengalis.

Key words: A.F.B, blood groups

\section{INTRODUCTION}

One of the earliest attempts to find out an association between blood groups and disease was done by Buchannan and Hursley (1921-1922), they studied 2446 patients and found that there was no relationship between blood groups and any disease. Aird et al. ${ }^{1}$, Fraser Robert ${ }^{2}$ and Tyagi et al. ${ }^{3}$ they all tried to established the relation between blood groups and various diseases. Many workers have tried to find out a possible correlation between the $\mathrm{ABO}$ blood groups and the incidence of various diseases. Strong association have been described between peptic ulcer and blood group $\mathrm{O}$, gastric carcinoma ${ }^{4}$ and blood group A, carcinoma cervix and pernicious anaemia in persons with blood group A, rheumatic heart disease ${ }^{5}$ with a lack of group $\mathrm{O}$, and HIV infection in group $\mathrm{O}$ persons ${ }^{6}$.

Discovery of the ABO system by Landsteiner in 1901 marked the beginning of safe blood transfusion. $\mathrm{ABO}$ blood group antigens are strong and contributory factor

\footnotetext{
Address for correspondence: Dr. D.K.Mishra

Sonoscan Diagnostic Centre, Subha Majumdar Sarani

Matrisadan, Balurghat, Dakshin Dinajpur

West Bengal - 733101, India

Mobile: 09333697176,09474839199

Email: mishra_dk29@yahoomail.co.in
}

DOI: 10.5530/ijmedph.4.2011.13 for person identity and individuality ${ }^{7}$. This blood group antigens are present on the surface of R.B.Cs and their naturally occurring antbodies circulate in the serum.

This study was done to establish the possible corerlation between the blood group and acid fast bacilli cases and also to know the frequency of distribution of $\mathrm{ABO}$ group in north Bengalis, India.

\section{MATERIAL AND METHODS}

This study was done in Sonoscan Diagnostic centre Dakshin Dinajpur West Bengal and includes 44 Acid fast bacilli positive patients who came here for the sputum examination and for the Fine needle aspiration and cytology of lymph node swelling and 3476 nontuberculous healthy person who came our diagnostic centre for the blood grouping in the month of July 2008 to December 2010. Zeihl Neelson stain was done for the Acid fast bacilli examination of sputum and aspirated material from Fine needle aspiration and cytology. Blood groups of above all the patients were determined by testing the individual's red blood corpuscles with various antisera and by identifying antibodies in his own serum by testing against cells containing known antigens. These patients data are analysed to know the possible correlation of A.F.B and blood group and also to know the frequency of distribution of $\mathrm{ABO}$ blood groups in north Bengalis. 


\section{OBSERVATION AND RESULTS}

Total numbers of A.F.B positive cases studied was 44 and total numbers of non-tubercular patients tested for blood groups as a representative of general population in this study was 3476. During the study period it was observed that A.F.B Positive cases were more common in blood group "O" patients and commonest blood group in North Bengalis have blood group "B".

\section{DISCUSSION}

In one hand this study deals with the association of all A.F.B positive cases with $\mathrm{ABO}$ blood groups and on the other hand it deals with the frequency of distribution of ABO blood groups among North Bengalis.

A.F.B positive cases were more common in blood group O (40.91\%),blood group B (31.82\%), than in blood group A (22.73\%) and least affected blood group was AB $(2.27 \%)$ as observed in table I. Reports in literature has shown a great variation in pulmonary tuberculosis and ABO blood groups. Study done by $\mathrm{RaO}^{8}$ in 250 patients of pulmonary tuberculosis reported an increase incidence of pulmonary tuberculosis in blood group $\mathrm{O}$ followed by blood group B. Saha ${ }^{9}$ studied in 2275 adult Chinese patients of pulmonary tuberculosis and observed that pulmonary tuberculosis were more common among patients of blood group B and blood group AB. Laha

\begin{tabular}{|c|c|c|c|}
\hline $\begin{array}{l}\text { Blood } \\
\text { group }\end{array}$ & $\begin{array}{l}\text { Rhesus } \\
\text { type }\end{array}$ & $\begin{array}{l}\text { Number of A.F.B } \\
\text { positive cases }\end{array}$ & $\begin{array}{l}\text { Percentage of } \\
\text { A.F.B cases }\end{array}$ \\
\hline $\bar{A}$ & + & 10 & 22.73 \\
\hline B & + & 14 & 31.82 \\
\hline 0 & + & 18 & 40.91 \\
\hline 0 & - & 01 & 2.27 \\
\hline$A B$ & + & 01 & 2.27 \\
\hline All & & 44 & 100 \\
\hline
\end{tabular}

\begin{tabular}{|c|c|c|c|}
\hline $\begin{array}{l}\text { Blood } \\
\text { group }\end{array}$ & $\begin{array}{c}\text { Rhesus } \\
\text { type }\end{array}$ & $\begin{array}{l}\text { Number } \\
\text { of cases }\end{array}$ & $\begin{array}{c}\% \text { of } A B O \\
\text { group }\end{array}$ \\
\hline$A$ & + & 868 & 24.98 \\
\hline B & + & 1236 & 35.56 \\
\hline 0 & + & 986 & 28.36 \\
\hline$A B$ & + & 284 & 08.17 \\
\hline$A$ & - & 12 & 00.34 \\
\hline$B$ & - & 48 & 01.38 \\
\hline 0 & - & 36 & 01.04 \\
\hline$A B$ & - & 06 & 00.17 \\
\hline All & & 3476 & 100 \\
\hline
\end{tabular}

and Dutta ${ }^{10}$ also reported blood group $\mathrm{O}$ patients have higher frequency of pulmonary tuberculosis. Thamaria et $a l^{11}$ in their 118 cases of pulmonary tuberculosis observed preponderance of this disease in patients of $\mathrm{O}$ blood group, where as Streng and Ryti ${ }^{12}$ found a decrease frequency of pulmonary tuberculosis in blood group $\mathrm{O}$. Gupta $^{13}$ and Jain ${ }^{14}$ mentioned higher frequency of pulmonary tuberculosis in blood group AB. Campbell ${ }^{15}$, Shenoy and Daftry ${ }^{16}$ did not found direct correlation between blood group and pulmonary tuberculosis.

According to Emerly ${ }^{17}$ it is difficult to explain that pulmonary tuberculosis is inherited because only small proportion of genetically predisposed person developed pulmonary tuberculosis, so general health, nutritional status of patients and exposure to infections are most important factor for development of tuberculosis than the genetic factor.

The second part of this study showed that there was preponderance of blood group B (35.56\%) followed by blood group O (28.36\%), blood group A (24.98\%) and least common blood group $\mathrm{AB}(0.17 \%)$ was observed among North Bengalis (Table II).

Sen et al. ${ }^{18}$ and Talwar et al. ${ }^{19}$ in their study reported prepondrace of blood group B in Bengalis and Punjabis respectively. Thamaria et al. ${ }^{11}$ observed preponderance of blood group $\mathrm{O}$ followed by B in their study from northern Rajasthan. Anand et al. ${ }^{20}$ reported group $\mathrm{O}$ commonest in Kashmiris,where as Verma ${ }^{21}$ reported group A preponderance in Sikkimis. Shenoy and Daftry ${ }^{16}$ studied blood groups in two series in Bombay and they found B group commonest in serirs I and O group in series II study among general population.

\section{CONCLUSION}

This study concludes that large number of cases and large area required to establish the correlation between $\mathrm{ABO}$ groups and A.F.B positive cases. However in this study it was observed that A.F.B positive cases are more common in blood group $\mathrm{O}$ and commonest blood group among north Bengalis were B. Blood grouping analysis is done in this region with the hope that they may used by health planners as a reference to implement blood donation programme during natural calamities and war like conditions.

\section{REFERENCES}

1. Aird I, Bentall HH, Fraser Roberts JA:(1953) Brit. Med. Jour, 1, 799.

2. Fraser Roberts JA: (1957) Brit. Jour. Prev. Soc. Med. 11,107. 
3. Tyagi SP, Hameed S Jain K.C: (1966) Indian Med. Gaz 6. 4.

4. Peptic ulcer disease and related disorders. In: valle John Del, editors Fauci, Braunwald, Kasper, Hauser, Longo et al. Harrison Principles of Internal Medicine.Vol II.17th.New York :McGraw Hill inc, 2008:1855-60.

5. Genetics and health.PARK K., Preventive and social medicine.20th edn. India,2009:724-33.

6. Sayal SK, Das AL, Nema SK, Study of blood groups in HIV seropositive patients Indian J Dermatol Venereol Leprol [serial online] 1996 [cited 2008 Oct 22];62:295-7.

7. Red cell blood-group antigens and antibodies In: revised by Watres $\mathrm{AH}$ editors Sir Daice John V.,and Lewis-PracticalM. haematology. 8th edn. ELBS; 1994:446-50.

8. Sukesh Rao, Pulmonary Tuberculosis And ABO Blood Groups - An Association? Lung India;1994. vol 12:35-36.

9. Saha N,Distribution of $A B O$ and Le ${ }^{a}$ blood groups in pulmonary tuberculosis in Chinese: clinical genetics;1973:4:288-290.
10. Laha PN Datta M: (1963) J. Ass. Physician India, 11, 287.

11. Thamaria JP, Mathur KC Husain SA:(1972) Indian J. Tub, 19, 30.

12. Streng O. Ryti El (1927) Quoted byAllan, T.M. 1955.

13. Gupta MC, Gupta SR: (1966) Indian J, Med.Sci.,20, 353

14. Jain RC (1970) Tubercle, 51, 322

15. Campbell AE: (1956) Tubercle, 37; 88.

16. Shenoy MA Daftery VG: (1962) Indian J.Med.Sci, 16,493.

17. Emery AEH.: (1968) Elements of Medical Genetics, Ed. 1st E. \& S. Livingtone Ltd. London, p. 112.

18. Sen NN, Mukerjee CL Aikat BK. (1959) J. Ind. Med. Assoc., 33:210.

19. Talwar C.L and Sawney C.P.(1958), Ind.J. Med. Science. 12:942.

20. Anand B.R. and Kanta Chander (1963) Curr. Med. Pract, 7: 507.

21. Verma N.K. (1970) Curr. Med. Pract., 14: 363. 